\title{
Geographic Information System for Schools Mapping in Tugumulyo District, Musi Rawas Regency
}

\section{Sistem Informasi Geografis Pemetaan Sekolah Kecamatan Tugumulyo Kabupaten Musi Rawas}

\author{
Hutrianto $^{1}$, Baibul Tujin ${ }^{2}$ \\ ${ }^{1}$ Fakultas Ilmu Komputer, Universitas Bina Darma, Palembang, Indonesia \\ ${ }^{2}$ Fakultas Vokasi, Universitas Bina Darma, Palembang, Indonesia \\ Email: 1hutrianto@binadarma.ac.id, 2baibul@binadarma.ac.id
}

\begin{abstract}
Schools are institutions that provide educational services to the community formed by the government in the form of organizational means to educate the nation's life. To guarantee the implementation of good education and in accordance with regulations set by the government, each school or school educational institution must follow accreditation. The spread of school locations certainly makes it difficult to access for assessors when they are going to do an accreditation assessment. In addition, other constraints experienced by the unavailability of school location information can be used as a reference for assessors in the accreditation assessment process. Under these conditions, it will certainly cause problems or obstacles in the accreditation process such as (1) the accreditation assessment process is not on schedule, (2) inaccurate assessment of the schedule, and (3) the quality of the accreditation assessment itself. Based on these conditions, in this study the development of a school mapping geographic information system can be used as a means of information for assessors in conducting accreditation assessments. the results of research that has been done show that geographic information systems can provide information on the distribution of schools both middle and upper levels. The information system can also function properly based on test results.
\end{abstract}

Keywords: GIS, School Mapping, Accreditation

\section{PENDAHULUAN}

Sekolah merupakan lembaga yang memberikan layanan pendidikan kepada masyarakat yang dibentuk oleh pemerintah dalam bentuk sarana organisasi untuk mencerdaskan kehidupan bangsa [1]. Sekolah memiliki jenjang yang berbedabeda yaitu mulai dari sekolah sekolah dasar (SD), sekolah menengeah pertama (SMP), sampai dengan sekolah menengah atas (SMA). Lembaga pendidikan sekolah memiliki fungsi utama yaitu membuat para siswa menjadi cerdas bukan 
sebera cerdas siswa yang ada [2]. Untuk itu sekolah menjadi lembaga yang penting bagi sebuah negara sebagai sarana untuk mencapai mencerdaskan anak bangsa. Tingkatan sekolah selain dari yang telah dikemukakan diatas terdapat tingkatan lain yang setara namun focus utama pada bidang umum dan agama. Tingkatan sekolah tersebut meliputi madrasyah ibtida'iyah (MI), madrasyah tsanawiyah (MTs), dan mahrasyah aliyah (MA). Sistem pendidikan yang ada pada lembaga sekolah ini memiliki kesamaan dalam proses dan manajemen pendidikannya. Namun yang membedakan keduanya terletak pada kementrian yang menaungi. Sekolah SD, SMP dan SMA dinaungi oleh Kementrian Pendidikan dan Kebudayaan sedangkan MI, MTs, dan MA dinaungi oleh Kementrian Agama.

Untuk menjamin pelaksanaan pendidikan yang baik serta sesuai dengan peraturan yang telah ditetapkan oleh pemerintah maka setiap sekolah atau lembaga pendidikan sekolah harus mengikuti akreditasi. Proses akreditasi sekolah merupakan tahapan verifikasi secara menyeluruh terhadap kinerja sebuah sekolah baik yang dilihat dari kelayakan maupun program kerja. Tujuan dari akreditasi sendiri untuk mencapai kepuasan publik (akuntabilitas publik) [3]. Untuk melakukan proses akreditasi pada sebuah lembaga pendidikan sekolah tidakla mudah untuk dilakukan, terutama lembaga pendidikan sekolah yang jauh dari pusat kota. Untuk melakukan akreditasi terdapat petugas khusus yang kenal dengan nama asesor sebagai perpanjangan tangan dari pemerintah. Menyebarnya lokasi sekolah tentunya menyulitkan akses bagi asesor ketika akan melakukan asesmen akreditasi. Selan itu juga kendala lain yang dialami tidak tersedianya informasi lokasi sekolah yang dapat dijadikan rujukan bagi asesor dalam proses asesmen akreditasi. dengan kondisi tersebut maka tentunya akan menimbulkan masalah atau kendala dalam proses akreditasi seperti (1) proses asesmen akreditasi tidak sesuai jadwal, (2) penjdawalan asesmen yang tidak akurat, dan (3) kualitas asesmen akreditasi itu sendiri.

Kondisi tersebut sebenarnya dapat diatasi dengan cara disediakannya sebuah mekanisme penyajian informasi berupa sistem informasi yang dapat memberikan pemetaan dan sebaran sekolah yang menjadi objek akreditasi. salah satu jenis sistem informasi yang mampu untuk menyajikan infomrasi tersebut adalah sistem informasi geografis (SIG). SIG adalah jenis sitem informasi yang dibuat untuk memberikan informasi spasial berdasarakan keruangan [4]. SIG juga dapat menampilkan informasi tidak hanya data atribut spasial namun juga memiliki kemampuan untuk menampilkan informasi objek secara detail berdasrakan info grafis dalam bentuk gambar peta berserta informasi yang terkait di dalammnya [5]. Pemanfaatan SIG sendiri dapat dilakukan dalam berbagai hal terutama dalam perencanaan ruang. Pemenfataan tersebut seperi dalam bindang Kawasan industryi, lembaga pendidikan dan pemukiman $[6,7]$. 
Untuk itu sesuai dengan kondisi yang telah dikemukakan maka dalam penelitian ini akan dilakukan pengembangan sistem informasi geografis (SIG) yang dapat digunakan sebagai penyajian infomrasi pemetaan atau sebaran sekolah yang dapat digunakan sebagai alat bantu dalam proses asesmen akreditasi sekolah. Agar proses pengembangan SIG dapat sesuai dengan tujuan maka dalam uji coba dilakukan pada Kecamatan Tugumulyo Kabupaten Musi Rawas.

\section{METODE}

Untuk mencapai tujuan yang telah dikemukakan maka dalam penelitian ini penyajian hasil penelitian digunakan metode kualitatif. Metode ini merupakan metode yang menekankan pada penjelasan fakta yang terjadi berdasarkan pada kondisi atau fenomena yang dialami oleh peneliti [8]. Sedangkan proses pengembangan SIG digunakan metode waterfall dengan lima tahapan utama yaitu komunikasi, perencanaan, pemodelan, kontruksi dan penyatuan (deployment) [9]. Gambar 1 dapat dilihat merupakan tahapan dalam pengembangan menggunakan waterfall.

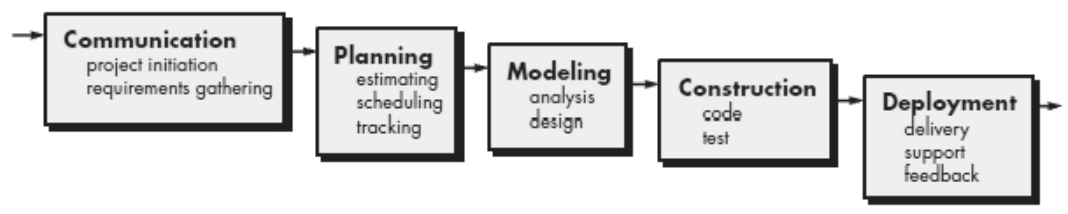

Gambar 1. Metode W aterfall [9]

Sesuai dengan Gambar 1 merupakan proses pengembangan dengan waterfall maka dapat dijelaskan sebagai berikut.

a. Communication, pekerjaan yang dilakukan pada tahapan ini yaitu melakukan analisis untuk medapatkan kenutuhan sistem informasi. selain itu juga dilakukan pengumpulan informasi/data yang dianggap perlu dalam proses pengembangan.

b. Planning, proses pekerjaan yang dilakukan pada tahapan ini yaitu melakukan perencanaan dalam pengerjaan sistem informasi geografis pemetaan sekolah di lingkungan Kecamatan Tugumulyo. Perencanaan yang dibuat berupa timeline kegiatan dan penyusunan daftar kebutuhan yang harus diselesaikan dalam proses pengembangan.

c. Modeling, pekerjaan yang dilakukan pada tahapan ini yaitu melakukan pembuatan model atau alur dari sistem informasi yang akan dihasilkan.

b. Construction, pekerjaan yang dilakukan pada tahapan ini yaitu melakukan yaitu melakukan pengkodean. Pengkodean yang dibuat mengikuti hasil modeling. Setelah selesai pengkodean dilakukan pengujian sistem infromasi.

c. Deployment, merupakan tahapan akhir yaitu melakukan persiapan delivery product. Selain itu juga dilakukan pemeliharaan terhadap product. 


\section{HASIL DAN PEMBAHASAN}

Dari penelitian yang penulis lakukan, didapatkan sebuah Sistem Informasi Geografis Pemetaan Sekolah Di Kecamatan Tugumulyo Kabupaten Musirawas yang dikhusus untuk menampilkan informasi pemetaan lokasi sekolah.

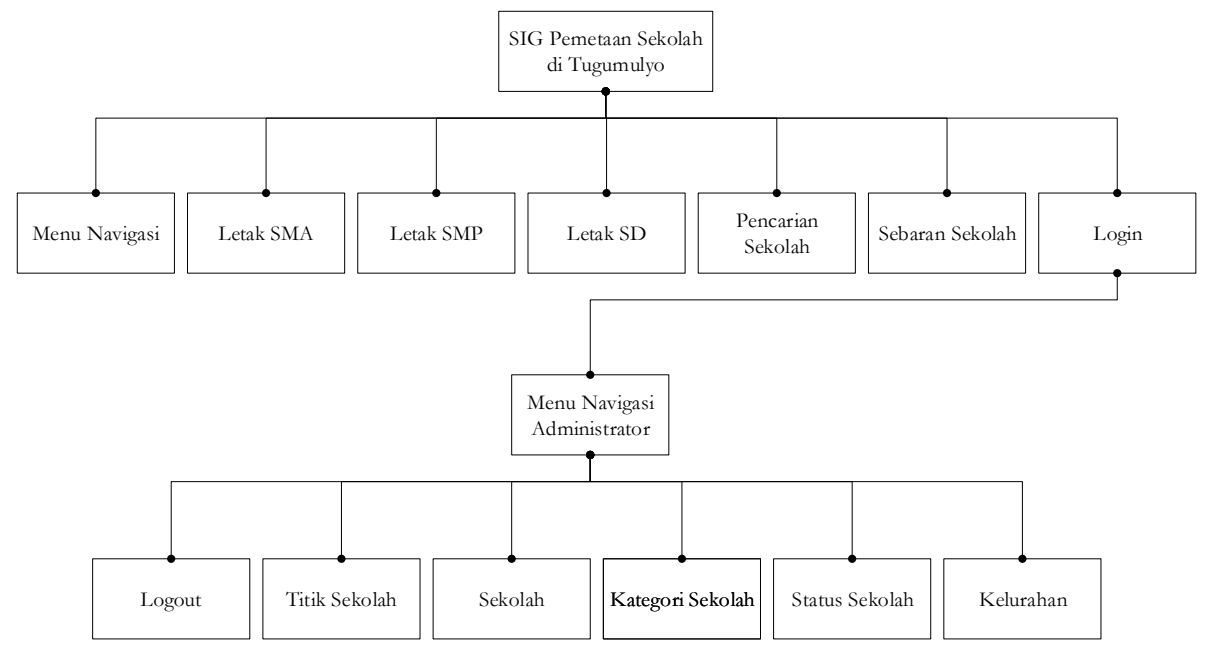

Gambar 2. Struktur Site Map SIG Sekolah

Struktur Site Map seperti pada Gambar 2 merupakan gambaran SIG Pemetaan Sekolah yang dihasilkan. Untuk itu dapat dijelaskan masing-masing informasi yang dapat digunakan sebagai berikut.

1. Halaman Menu Navigasi, Halaman Dashboard merupakan halaman utama yang merupakan tampilan utama dari Sistem Informasi Geografis Pemetaan Sekolah.

2. Halaman Letak SMA, Halaman ini adalah halaman yang berisikan informasi sebaran sekolah SMA.

3. Halaman Letak SMP, halaman letak SMP adalah halaman yang berisikan informasi sebaran sekolah.

4. Halaman Letak Madrasah, halaman letak madrasah adalah halaman yang berisikan informasi sebaran sekolah.

5. Halaman Pencarian Sekolah, Halaman pencarian sekolah adalah halaman melakukan pencarian letak sekolah.

6. Halaman Sebaran Sekolah, halaman seberan sekolah adalah halaman yang berisikan informasi sebaran sekolah-sekolah atau semua sekolah di sistem informasi pemetaan sekolah.

SIG pemetaan sekolah bertujuan untuk memberikan informasi lokasi sekolah serta letak keberadaanya sehingga masyarakat luas dapat memperoleh informasi 
umumnya dan asesor akreditasi pada khususnya secara cepat, tepat, dan akurat. Dari site map seperti yang diperlihatkan pada Gambar 2 maka dapat dijelaskan masing-masing komponen menu tersebut.

\subsection{Sebaran Letak SMA}

Sebaran letak SMA berisikan informasi lokasi-lokasi SMA. Pada letak SMA berisikan informasi SMA seperti nama sekolah, status sekolah, kelurahan, alamat, telepon dan nama kepala sekolah. Pada Gambar 3 terlihat tampilan halaman pemetaan letak SMA.

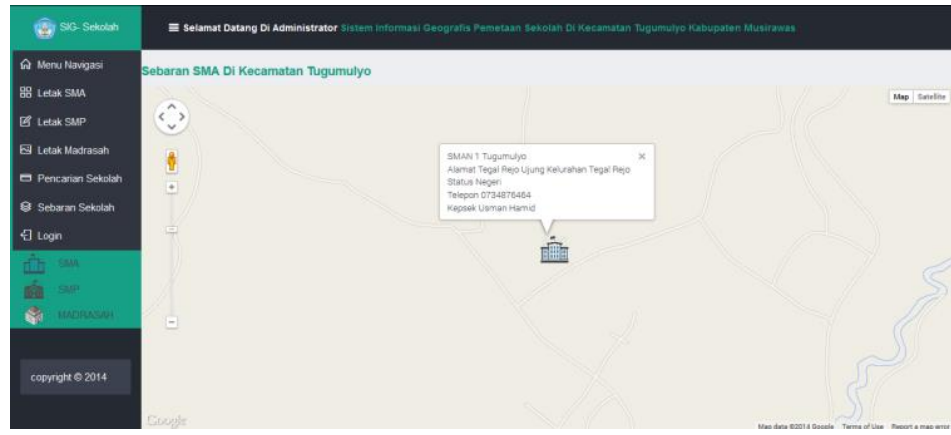

Gambar 3 Halaman Letak SMA

\subsection{Sebaran Letak SMP}

Sebaran letak SMP berisikan informasi lokasi-lokasi SMP yang ada SIG pemetaan sekolah seperti pada Gambar 4. SMP yang ada adalah hasil penginputan oleh administrator sistem informasi geografis pemetaan Sekolah. Informasi atribut yang ditampilkan memiliki kesamaan dengan atribut pada letak SMA yaitu nama sekolah, status sekolah, kelurahan, alamat, telepon dan nama kepala sekolah.

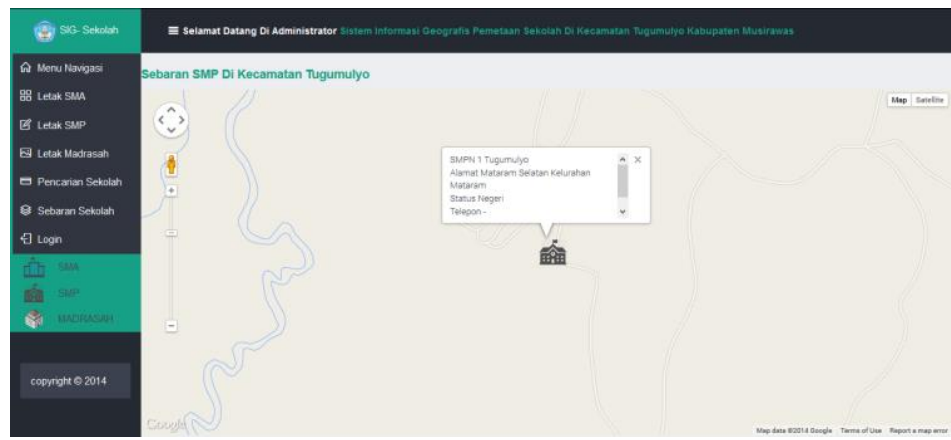

Gambar 4 Halaman Letak SMP

\subsection{Sebaran Letak Madrasah}


Sebaran letak Madrasah berisikan informasi lokasi-lokasi madrasah sistem informasi geografis pemetaan sekolah. Informasi non spasial yang ditampilkan memiliki kesamaan dengan letak SMA dan letak SMP yaitu nama sekolah, status sekolah, kelurahan, alamat, telepon dan nama kepala sekolah. Madrasayah yang ditampilkan pada halaman ini meliputi untuk tingkat MI, MTs, dan MA. Tampilan sebaran letak madrasah seperti yang diperlihatkan pada Gambar 5.

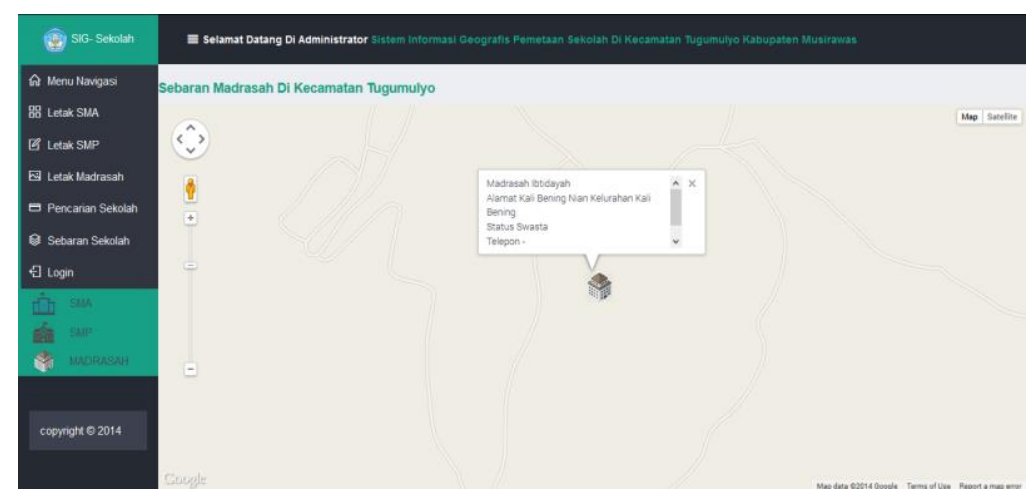

Gambar 5. Sebaran Letak Madrasah

\subsection{Pencarian Sekolah}

Proses pencarian sekolah merupakan salah satu fitur yang disediakan didalam SIG pemetaan sekolah. Untuk melakukan pencarian pengguna hanya dapat memilih sekolah maka lokasi sekolah dapat ditampilkan seperti yang diperlihatkan pada Gambar 6.

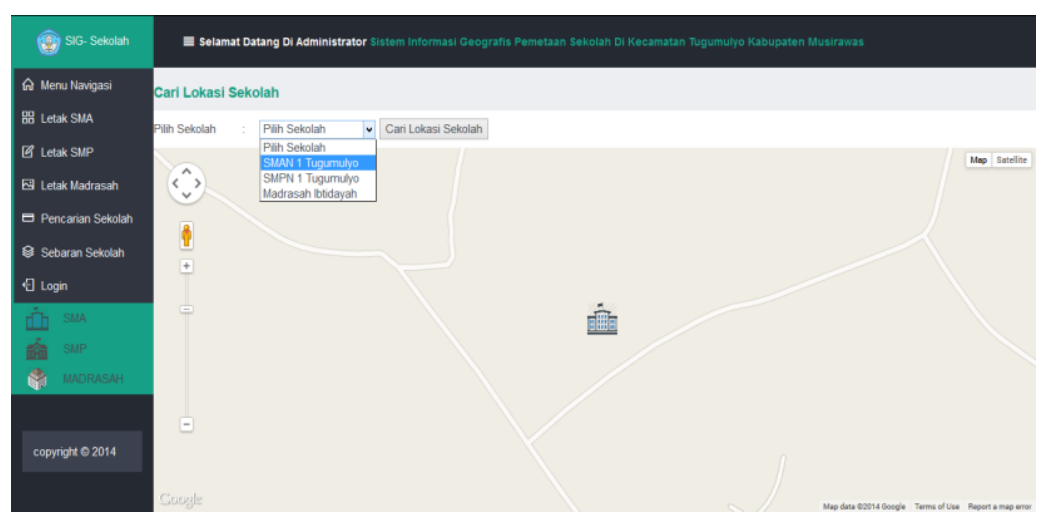

Gambar 6. Halaman Pencarian Sekolah

Selain dapat melakukan pencarian pengguna juga dapat melihat semua sebaran sekolah di Kecamatan Tugumulyo. Infromasi sekolah yang di tampilkan sistem 
informasi geografis pemetaan sekolah terdisi dari sekolah menengah Atas, sekolah menengah pertama dan sekolah madrasah. Informasi yang ada pada titiktitik sekolah adalah nama sekolah, status sekolah, kelurahan, alamat, telepon dan nama kepala sekolah. pada sistem informasi geografis pemetaan sekolah ini juga terjadi perbedaan icon untuk masing-masing kategori sekolah. Masing-masing icon tersebut dibuat untuk membedakan dari kategori sekolah yaitu SMA, SMP dan Madrasah. Pada Gambar 7 dapat dilihat tampilan dari sebarang sekolah.

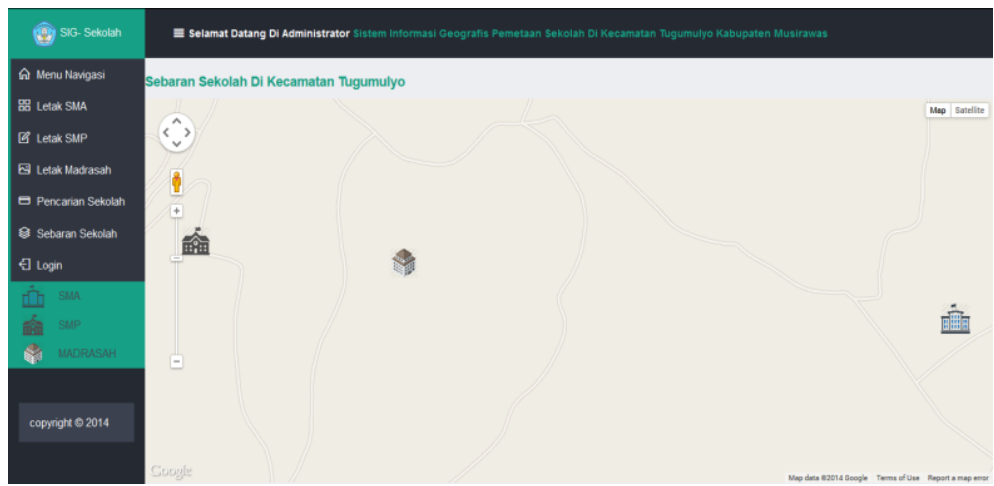

Gambar 7. Halaman Sebaran Sekolah

\subsection{Pengujian}

Sebagai langkah akhir dalam proses pengembangan sistem informasi geografis pemetaan sekolah maka dilakukan pengujian. Teknik pengujian yang digunakan yaitu black box dengan melakukan pengataman atara masukkan dan keluaran sistem informasi [10]. Tabel 1 merupakan hasil pengujian yang telah dilakukan.

Tabel 1. Hasil Pengujian Komponen SIG

\begin{tabular}{llc}
\hline Komponen Uji & Metode Uji & Diterima \\
\hline Pengelolaan Data Kelurahan & $\begin{array}{l}\text { Black Box (Pengamatan } \\
\text { dalam proses } \\
\text { pemasukkan, perubahan, }\end{array}$ & YA \\
& $\begin{array}{l}\text { penghapusan dan } \\
\text { penampilan data) }\end{array}$ & \\
& & YA \\
& $\begin{array}{l}\text { Black Box (Pengamatan } \\
\text { dalam proses } \\
\text { pemasukkan, perubahan, } \\
\text { penghapusan dan } \\
\text { penampilan data) }\end{array}$ & \\
&
\end{tabular}




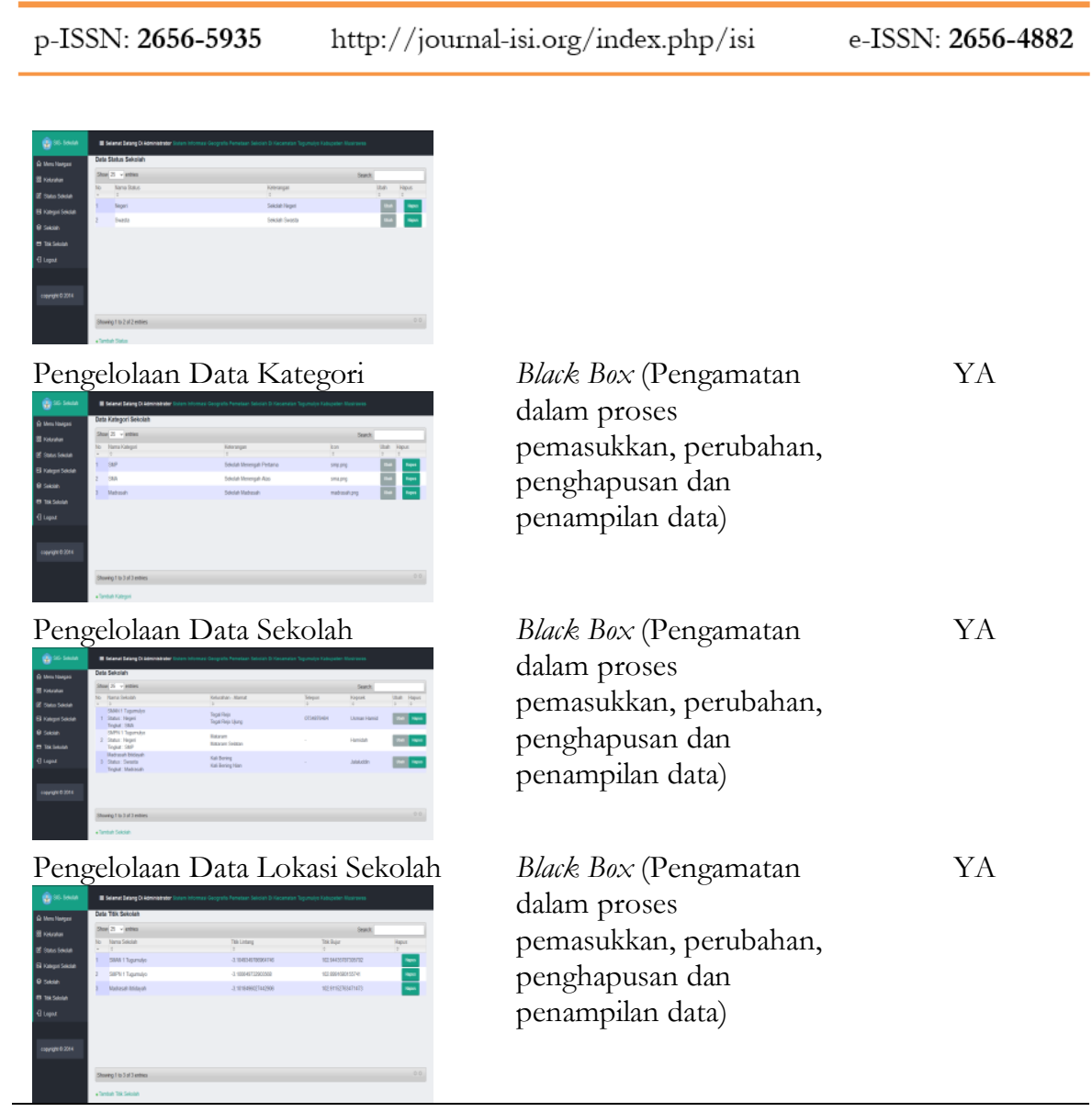

\section{KESIMPULAN}

Sesuai dengan uraian yang telah dikemukakan berkaitan dengan sistem informasi geografis pemetaan sekolah maka dapat disimpulkan beberapa hal yaitu: (1) sistem informasi yang dihasilkan memiliki fitur yang dapat memberikan informasi sebaran sekolah yang terdiri dari sekolah umum dan madrasyah. (2) informasi yang ditampilkan dapat dijadikan informasi awal bagi asesor ketika akan melakukan asesmen akreditasi ke sekolah. (3) sistem informasi geografis pemetaan sekolah memiliki fitur atau komponen yang berfungsi dengan baik sesuai dengan hasil pengujian yang dilakukan.

\section{REFERENSI}

[1] S. K. Wardani, "Sistem Informasi Pengolahan Data Nilai Siswa Berbasis Web Pada Sekolah Menengah Atas (SMA) Muhammadiyah Pacitan," IJNS-Indonesian Journal on Networking Security, vol. 2, no. 2, 2013. 
[2] M. Chatib, Sekolah anak-anak juara: berbasis kecerdasan jamak dan pendidikan berkeadilan. Kaifa, 2012.

[3] M. H. Rahman, S. Saprudin, H. Mubarak, and F. Hamid, "Evaluasi Program IbM Pendampingan Penyusunan Borang Akreditasi Bagi Sekolah Dasar di Kota Ternate," Titian Ilmu: Jurnal Ilmiah Multi Sciences, vol. 9, no. 2, pp. 59-65, 2017.

[4] A. Aini, "Sistem Informasi Geografis Pengertian dan Aplikasinya," STMIK AMIKOM Yogyakarta, vol. 13, 2007.

[5] A. Q. Munir, "PERANCANGAN SISTEM INFORMASI GEOGRAFIS PENENTUAN JALUR JALAN OPTIMUM KODYA YOGYAKARTA MENGGUNAKAN ALGORITMA DIJKSTRA," Jumal Teknologi Informasi Respati, vol. 7, no. 19, 2017.

[6] U. Ependi, "Geographic Information System Sebaran SMA Di Kota Palembang Berbasis Web," in Seminar Nasional Inovasi dan Tren (SNIT) 2014, 2014, pp. 108-113: LPPM BSI.

[7] U. Ependi, "Geographic Information System Produksi Energi dan Pertambangan Kabupaten Musi Banyuasin," Jurnal Nasional Teknologi dan Sistem Informasi, vol. 3, no. 3, pp. 360-369, 2017.

[8] U. Ependi, T. B. Kurniawan, and F. Panjaitan, "SYSTEM USABILITY SCALE VS HEURISTIC EVALUATION: A REVIEW," Simetris: Jurnal Teknik Mesin, Elektro dan Ilmu Komputer, vol. 10, no. 1, pp. 65-74, 2019.

[9] R. S. Pressman, "Rekayasa Perangkat Lunak Pendekatan Praktisi (Edisi 7)," Yogyakarta: Andi, 2011.

[10] U. Ependi, "Uji Coba Dan Implementasi Test Engine System Bina Darma Career And Training Center," Jurnal Nasional Teknologi dan Sistem Informasi, vol. 9, no. 1, pp. 1222-1232, 2017. 